Published by Al-Nahrain College of Medicine P-ISSN 1681-6579 E-ISSN 2224-4719

Email: iraqijms@colmed-alnahrain.edu.iq http://www.colmed-alnahrain.edu.iq http://www.iraqijms.net Iraqi JMS 2018; Vol. 16(2)

\title{
Crimean-Congo Hemorrhagic Fever in the Middle East: History and Facts
}

\author{
Asmaa B. Al-Obaidi PhD Microbiology (Virology) \\ Dept. of Microbiology, College of Medicine, Al-Nahrain University, Baghdad, Iraq
}

\begin{abstract}
Crimean-Congo Hemorrhagic Fever (CCHF) is the highest widespread, tick-borne viral hemorrhagic fever that affect humans. This virus is endemic in many areas in the world, such as Africa, Asia, and Europe. Nowadays, the incidence of CCHF is increasing rapidly in several countries of the middle-east, with several outbreaks and sporadic cases in human of CCHF, that are reported in several countries in this region.
\end{abstract}

Keywords CCHF, Middle east, Iraq

Citation Al-Obaidi AB. Crimean-Congo hemorrhagic fever in the middle east: history and facts. Iraqi JMS. 2018; 16(2): 111-113. doi: 10.22578/IJMS.16.2.1

List of abbreviation: $\mathrm{CCHF}=$ Crimean-Congo hemorrhagic fever, ssRNA = Single stranded RNA

\section{Introduction}

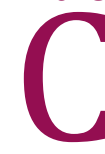

rimean-Congo haemorrhagic fever virus (CCHF), genus Nairovirus, family Bunyaviridae, is an enveloped- with a negative-sense ssRNA genome, causes zoonotic disease in many countries of Africa, Asia, Middle East and southeastern Europe ${ }^{(1-3)}$.

The distribution of CCHF virus coincides with the distribution of its vector; ticks of genus Hyalomma, makes the spread of these infected ticks into new unaffected areas to facilitate the spread of CCHF virus. The virus circulating in a tick-vertebrate-tick life cycle. These ticks infest on wide spectrum of wildlife animals, and livestock animals, e.g. cattle, sheep, and goat $(3,4)$.

Viremia in these livestock is of short lived and low intensity. The livestock animals play a very important role in life cycle of ticks, and in amplifying and transmitting the virus and are, therefore, the focus of veterinary public health, however, animals do not develop clinical signs, while the virus causes significant human illness (4-7).

\section{Disease characteristics}

Infection acquired in humans from bites of tick, or from contact with the infected blood or tissues of livestock or human patients. After a 3-7 days incubation period, the patient can develop severe disease, with a prehemorrhagic phase, a hemorrhagic phase, and then a convalescence period. The hemorrhagic manifestations can range from small petechiae to large-hematomas. Bleeding could be from the nose, gastrointestinal tract, respiratory tract, urinary tract, and uterus, with a mortality rate range from $5 \%$ to $80 \%(3,8,9)$.

The severity of this infection in humans focus the impact of this zoonotic disease on public health. Serological screening of animal serums for CCHF virus-specific antibodies is very important. Because the virus prevalence in animals is good indicator of the circulating local 
virus, these sero-prevalence studies allow the identification of high-risk areas of human infection (10).

Slaughterhouse workers, stockmen, and veterinarians, should be made aware of the disease. They should work on limiting or avoiding exposure of the naked skin to infected blood and tissues, and to avoid tick bites. In general, treatment of livestock could reduce tick density among these animals, and then reduce the of tick bite risks in these animal handlers ${ }^{(10)}$. The infectivity of CCHF virus can be destroyed by boiling low concentrations of formalin and lipid solvents ${ }^{(4)}$.

\section{Migration and Middle East outbreaks}

There are 7 CCHF viral genotypes: Africa-1, Africa-2, Africa-3, Asia-1, Asia-2, Euro-1, and Euro-2. According to the region in which they were first recognized and still circulate. However, more than one genotype can be found through multiple countries. This might suggest the migratory pattern of the virus and the appearance of outbreaks (11). CCHF described for the first time in 1944 in the Crimean Peninsula-Russia, and later in the Democratic Republic of the Congo in 1956, which later on gave its name Crimean-Congo. Firstly, this virus was widely reported in Africa, however, in recent years, outbreaks in the Middle East, Asia and Eurasia have become more common (2).

Studies suggested that CCHF virus is a migrating pathogen, however it is not clear this migration is to what extent. Mild et al. in 2010 have analyzed the worldwide migration pattern of CCHF virus, for the first time, their study found that Turkey could be the source of migration to Europe, both to the east and the west, and the United Arab Emirates is the source of migration to the Middle East ${ }^{(12)}$.

In 2002 and 2003, twelve patients in Turkey had proved CCHF virus infection that resemble the virus genotypes found in Russia and Kosovo very closely, and a different genotype from those that caused the outbreak of CCHF in Iran in the year 2002. These data proved that the disease in the affected areas in Turkey was not introduced from Iran whether by a livestock or from an infected tick ${ }^{(13)}$.

In 2009, Chinikar et al. reviewed the history of CCHF in Iran, showed that the disease was detected in Iran since 1970. However, the mortality rate was about $20 \%$ in 2000 and then dropped remarkably to $6 \%$ in $2007^{(14)}$. Iranian molecular studies demonstrated that the Iranian CCHF virus strains were very similar to the Pakistani Strain (15).

A study in Iraq's Sulaimani province in 2016, showed that CCHF is a rare viral infection in the Sulaimani province, and no proven reported cases, which is mainly due to the ticks' eradication which was done by the veterinary and agricultural authorities. However, other preventive measures and strategies could be carried out and always monitored by local Sulaimani authorities (16).

The World Health Organization (WHO) reported sporadic human cases and some outbreaks of CCHF virus in the Eastern Mediterranean area, mainly in Iran, Saudi Arabia, Iraq, Oman, Pakistan, Kuwait, and the United Arab Emirates. In these countries, CCHF was increasing in the recent years, and new cases are reported in new areas in this region, with a more geographic extension of this viral disease, which might be linked to the spread of infected ticks by the migratory birds and the trade in livestock. The rise in temperature and decrease in rainfall in the Eastern Mediterranean Region can lead to increase in the distribution of the habitats that are suitable for Hyalomma-ticks, which results in increase in the $\mathrm{CCHF}$ virus infection rates ${ }^{(17)}$.

\section{References}

1. Swanepoel R, Burt FJ. Crimean-Congo haemorrhagic fever. Second Edition. In: Coetzer JAW, Tustin RC (eds). Infectious diseases of livestock with special reference to South Africa. Cape Town: Oxford University Press Southern Africa; 2004. p. 1077-85.

2. International Committee on Taxonomy of Viruses. (2016).

URL:

http://www.ictvonline.org/virusTaxonomy.asp.

3. Ergonul O. Crimean-Congo haemorrhagic fever. Lancet Infect Dis. 2006; 6(4): 203-14. 
4. Swanepoel R, Paweska JT. Crimean-Congo hemorrhagic fever. In: Palmer SR, Soulsby L, Torgerson PR, et al. (eds). Oxford textbook of zoonosis: Biology, clinical practice and public health control. 2nd ed. UK: Oxford University Press; 2011. p. 287-93.

5. Avšič-županc T. Epidemiology of Crimean-Congo hemorrhagic fever in the Balkans. In: Ergonul $\mathrm{O}$, Whitehouse CA (eds). Crimean-Congo hemorrhagic fever, a global perspective. Dordrecht, Netherlands: Springer; 2007. p. 75-88.

6. Grard G, Drexler JF, Fair J, et al. Re-emergence of Crimean-Congo hemorrhagic fever virus in Central Africa. PLoS Negl Trop Dis. 2011; 5(10): e1350. doi: 10.1371/journal.pntd.0001350.

7. Papa A, Tzala E, Maltezou HC. Crimean-Congo hemorrhagic fever virus, Northeastern Greece. Emerg Infect Dis. 2011; 17(1): 141-3. doi: 10.3201/eid1701.100073.

8. Yilmaz GR, Buzgan $T$, Torunoglu $M A$, et al. $A$ preliminary report on Crimean-Congo haemorrhagic fever in Turkey, March-June 2008. Euro Surveill. 2008 Aug 14;13(33). pii: 18953.

9. Appannanavar SB, Mishra B. An Update on CrimeanCongo hemorrhagic fever. J Glob Infect Dis. 2011; 3(3): 285-92. doi: 10.4103/0974-777X.83537.

10. Mertens M, Schmidt K, Ozkul A, et al. The impact of Crimean-Congo hemorrhagic fever virus on public health. Antiviral Res. 2013; 98(2): 248-60.

11. Estrada-Peña A, Jameson L, Medlock J, et al. Unraveling the ecological complexities of tickassociated Crimean-Congo hemorrhagic fever virus transmission: a gap analysis for the western
Palearctic. Vector Borne Zoonotic Dis. 2012; 12(9): 743-52. doi: 10.1089/vbz.2011.0767.

12. Mild $M$, Simon $M$, Albert J, et al. Towards an understanding of the migration of Crimean-Congo hemorrhagic fever virus. J Gen Virol. 2010; 91(Pt 1): 199-207. doi: 10.1099/vir.0.014878-0.

13. Karti SS, Odabasi Z, Korten V, et al. Crimean-Congo hemorrhagic fever in Turkey. Emerg Infect Dis. 2004; 10(8): 1379-84. doi: 10.3201/eid1008.030928.

14. Chinikar S, Ghiasi SM, Ghalyanchi-Langeroudi A, et al. An overview of Crimean-Congo hemorrhagic fever in Iran. Iran J Microbiol. 2009: 1(1): 7-12.

15. Chinikar S, Persson SM, Johansson M, et al. Genetic analysis of crimean-congo hemorrhagic fever virus in Iran. J Med Virol. 2004; 73(3): 404-11. doi: 10.1002/jmv.20106.

16. Aziz TAG, Ali DJ, Jaff DO. Molecular and Serological Detection of Crimean-Congo hemorrhagic fever virus in Sulaimani Province, Iraq. J Bioscie Med. 2016; 4(4): 36-42. http://dx.doi.org/10.4236/jbm.2016.44006.

17. Al-Abri SS, Al Abaidani I, Fazlalipour M, et al. Current status of Crimean-Congo haemorrhagic fever in the World Health Organization Eastern Mediterranean Region: issues, challenges, and future directions. Int J Infect Dis. 2017; 58: 82-89. doi: 10.1016/j.ijid.2017.02.018.

\footnotetext{
E-mail: asmaa.viro@yahoo.com asmaa_baqer@colmed-alnahrain.edu.iq
} 